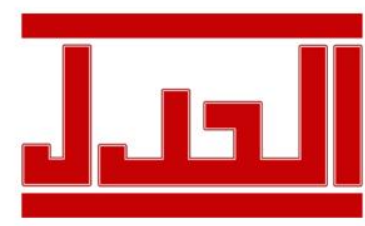

ISSN: $1979-4940$

E-ISSN: 2477-0124
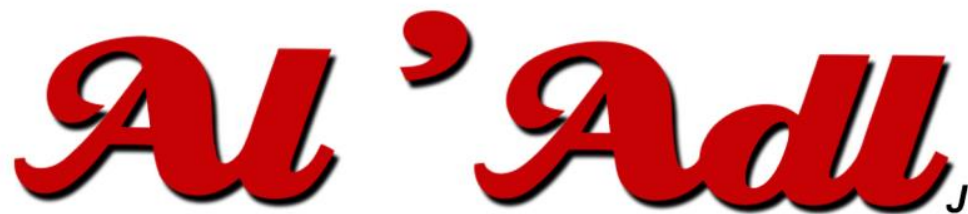

Jurnal Hukum

Editorial Office: Faculty of Law, Islamic University Of Kalimantan,

Jalan Adhyaksa No. 2 Kayutangi Banjarmasin, Kalimantan Selatan, Indonesia (70123)

Email: al_adl@uniska-bjm.ac.id

Web: http://ojs.uniska-bjm.ac.id

\title{
THE FUTURE POLICY OF SUSTAINABLE PLASTIC WASTE MANAGEMENT IN SOUTH KALIMANTAN PROVINCE
}

\author{
${ }^{(1)}$ Ifrani ${ }^{(2)}$ Muhammad Ali Amrin \\ Faculty of Law Lambung Mangkurat University \\ Jalan Brigjen H.Hasan Basry, Banjarmasin 70123, Indonesia \\ E-mail: ${ }^{[1]}$ ifrani@ulm.ac.id E-mail : ${ }^{[2]}$ amrin65ali@gmail.com
}

\begin{abstract}
Submitted $\quad: 10$ Februari 2021
Revised : 16 Februari 2021

Accepted :3 April 2021

Published : 30 April 2021
\end{abstract}

(C) Licence by CC BY-NC-SA

\begin{abstract}
Plastic waste management is currently a major problem in several countries, especially in Indonesia. Because plastic waste cannot be decomposed.

In South Kalimantan which is a wetland area, plastic waste is a serious problem that must be handled by the local government, due to the nature of wetlands that have a high water content or are inundated by water, either permanently or seasonally. The Non-decomposition of plastic waste will destroy wetlands. The specific objectives to be achieved are: (1) The legal policies that local governments take manage plastic waste in South Kalimantan. (2) The ideal future policy of plastic waste management to preserve the sustainability of wetlands. The method used to compile this research is doctrinal legal research. Legal research here does not merely examine the law as a statutory rule but also examines how the law has a positive effect on people's lives. The result shows that in drafting future policy/law the viewpoint must be established that the policy direction of the ius constituendum is not only aimed at providing protection of the right to the environment for humans but also changing the environmental paradigm and outlook towards Ecocentrism and Deep Ecology rather than the views of Anthropocentrism and Shallow Ecology.
\end{abstract}

Keywords : Plastic Waste, Management, Wetlands;

\section{INTRODUCTION}

The development has substantially changed the economy and society. The word "development" seems to indicate detention in the context of "revolution," which shows rapid 
changes $^{1}$; however least-developed countries face many challenges regarding their plastic waste management systems. While high-income countries face only the impacts of their own consumption, developing nations must endure the externalities of these developed economies. ${ }^{2}$ Plastic waste disposal is a major factor that causes environmental damage. Plastic bags have become dangerous and difficult to manage, it takes tens or even hundreds of years to completely decompose. Therefore the negative impact of plastic waste is as big as its function. ${ }^{3}$ When decomposed, plastic particles will pollute soil and groundwater. ${ }^{4}$ If burned, it will produce harmful toxic fumes, if the combustion process is not perfect, the plastic will break down in the air as dioxins. These compounds are highly dangerous if inhaled by humans..$^{5}$ The impact includes triggering cancer, hepatitis, swelling of the liver, nervous system disorders, and triggering depression. The plastic bag is also the cause of flooding because it clogs waterways, embankments. So that it resulted in flooding even the worst damage to the reservoir turbine. ${ }^{6}$

It is estimated that 500 million to one billion plastic bags are used in the world each year. Each year, about 500 billion - 1 trillion plastic bags are used worldwide. It is estimated that each person consumes 170 plastic bags each year. More than 17 billion plastic bags are distributed free of charge by supermarkets around the world each year. Plastic bags have begun to be used since the arrival of supermarkets in big cities. For wetland areas, the use of plastic bags is very dangerous. Apart from being non-biodegradable, it can also pollute the soil, which is mostly inundated by water, either permanently or seasonally. Banjarmasin City Government has issued Mayor Regulation No. 18/2016 on Reducing the Use of Plastic Bags, However, the use of plastic bags is still widely practiced in traditional markets. South

${ }^{1}$ Yati Nurhayati, Ifrani, Abdul Halim Barkatullah, M Yasir Said, (2019), "The Issue of Copyright Infringement in 4.0 Industrial Revolution: Indonesian Case", Jurnal Media Hukum, Vol.26, No. 2 December 2019, P.122-130.

${ }^{2}$ Thus, the focus of the least developed part of the world must not be on reducing its relatively normal (or even low) consumption, but to manage its surplus material flow. See Balint Horvath, Edmund Mallinguh, Csaba Fogarassy, (2018), "Designing Business Solutions for Plastic Waste Management to Enhance Circular Transitions in Kenya”, Sustainability, Vol.10, No.5, P.1664, https://doi.org/10.3390/su10051664

${ }^{3}$ Mangal Gogte, (2009), “Are Plastic Grocery Bags Sacking The Environment?”, International Journal For Quality Research, Vol. 3, No.4, PP. 363-375

4 Aneta K. Urbanek et.al., (2017), "Isolation and Characterization of Arctic Microorganisms Decomposing Bioplastics", AMB Express, Vol.7, No.1, PP. 1-10, https://doi.org/10.1186/s13568-017-0448-4

${ }^{5}$ Nurhenu Karuniastuti, (2013), "Bahaya Plastik Terhadap Kesehatan dan Lingkungan”, Jurnal Forum Teknologi, Vol. 03 No.1, P. 6-7.

${ }^{6}$ The use of a very large amount of plastic will certainly have a significant impact on human health and the environment because plastics are non-biodegradable, plastic is estimated to take 100 to 500 years to completely decompose. Thus the use of plastics, both new plastics and plastic waste, must comply with applicable requirements so that they are not harmful to health and the environment. 
Kalimantan as an area that is mostly a wetland area, needs to think about plastic waste management to maintain environmental harmony.

\section{PROBLEM IDENTIFICATION}

1. The legal policies that local governments take manage plastic waste in South Kalimantan.

2. The ideal future policy of plastic waste management to preserve the sustainability of wetlands.

\section{METODE PENELITIAN}

The research conducted to compile this research is doctrinal legal research. Legal research here does not merely examine the law as a statutory rule but also examines how the law has a positive effect on people's lives. ${ }^{7}$ Referring to the understanding that law is a means to organize change in society (law as a tool of social engineering), there is a functional relationship between law and society. ${ }^{8}$ Law as a means of social engineering means the conscious use of law to achieve an orderly state or society as aspired to, or to make the desired changes. ${ }^{9}$ Law is no longer seen merely as an order to guard the status quo but is also believed to be a system of regulation to achieve certain goals in a planned manner. So research on agricultural wetland areas in the perspective of sustainable development. The research location to obtain primary data was Banjarmasin City, South Kalimantan Province. Research conducted using primary data and secondary data. Primary data is research material in the form of empirical facts, namely human behavior, both in the form of verbal behavior, real behavior, and documented behavior. Primary data is needed in this study to strengthen/clarify secondary data. Secondary data is legal material in research obtained through library research consisting of primary legal materials, secondary legal materials, and materials, non-legal materials. The data used in this study are primary data and secondary

7 Yati Nurhayati, Ifrani, M.Yasir Said, (2021), "Metodologi Normatif dan Empiris Dalam Ilmu Hukum", Jurnal Penegakan Hukum Indonesia, Vol. 2, No.1, Januari 2021, P.1-20

${ }^{8}$ Soetandjo Wignjosoebtoto, (2002), Hukum-Paradigma, Metode dan Dinamika Masalahnya, Jakarta: ELSAM dan HUMA, P. 69

${ }^{9}$ M. Yasir Said \& Ifrani, (2019), Hukum Pidana Kehutanan Indonesia: Pergeseran Delik Pidana Kehutanan Menjadi Premium Remedium, Bandung: Nusa Media, P. 100 
data. Primary data collection was carried out through in-depth interviews with sources related to this research. Primary data sampling using the positive random sampling technique, this technique is used by considering the parties who are the sources with related agencies that determine policies related to plastic waste management in South Kalimantan province.

\section{RESULT AND DISCUSSION}

\section{The Government's Authority in Plastic Waste Management}

Article 28H (1) of the 1945 Constitution of the Republic of Indonesia gives every person the right to have a good and healthy environment. This norm provides a consequence that the government is obliged to provide public services in waste management. The result is that the government has a responsibility for waste management. ${ }^{10}$ Thus that in waste management will not be separated from the interference of the state and various sectors in society, including the business world. ${ }^{11}$ Also, the role of the community, which is a network or community of disposing of waste, has a big role in waste management, in this case, the recycling process to be reused. So that waste management is part of public services that must be regulated in regulations that are expected to provide comfort in the daily life of the community. ${ }^{12}$

To carry out integrated and comprehensive waste management, fulfillment of the rights and obligations of the community, as well as the duties and authorities of the Government and regional governments to carry out public services, a legal umbrella in the form of law is required. The legal arrangements for waste management in this Law are based on the principle of responsibility, the principle of sustainability, the principle of benefit, the principle of justice, the principle of awareness, the principle of togetherness, the principle of safety, the principle of security, and the principle of economic value. ${ }^{13}$

\footnotetext{
${ }^{10}$ Urban areas is currently faced with a variety of quite complex problems. These problems include the high rate of waste, bad human behavior and problems with waste disposal activities. In addition to this, in urban communities there is a consumptive culture that affects the improvement of the quality and type of waste. See Mele Caterina, (2019), "Human Settlements And Sustainability: A Crucial And Open Issue", E3S Web of Conferences, Volume 119, P.12, https://doi.org/10.1051/e3sconf/201911900012

${ }^{11}$ Balint Horvath, Edmund Mallinguh, Csaba Fogarassy, (2018), Op.Cit.

12 Nora-Charlotte Pauli, Jana S. Petermann, Christian Lott, Miriam Weber, (2017), "Macrofouling Communities and the Degradation of Plastic Bags in the Sea: An in Situ Experiment", Royal Society Open Science, Vol. 4, No. 10, P. 1, https://doi.org/10.1098/rsos.170549

${ }^{13}$ Mulyanto, (2013), "Sistem Pengelolaan Sampah Terpadu (Sipengestu) Kelurahan Serengan dalam Kajian Sosiologi Hukum”, Jurnal Parental, Vol. 1, No. 2 October 2013, P. 6
} 
Based on the mandate of Article 18 paragraph (2) and paragraph (5) of the 1945 Constitution of the Republic of Indonesia, it is stated that the Regional Government has the authority to regulate and administer Government Affairs by itself according to the Autonomy and Co-administered Tasks and is granted the widest possible autonomy. Based on this article and its explanation that the implementation of regional government must be based on the principles of decentralization, deconcentration, and assistance tasks. So that there is Act $32 / 2004$ which regulates the authority of both provincial and district/city governments regarding environmental control. Even though the Law was replaced by Act 23/2014 still gives authority to local governments. Article 12 of Act 23/2014 regulated that the authority of the local government (concurrent government) to carry out mandatory government affairs that are not related to basic services, one of which is the environment.

Act 32/2009 on Environmental Protection and Management (UUPPLH) regarding waste management for the government and local governments, cannot be separated from the principles contained in Article 2 of the UUPPLH which regulates the principles of state responsibility, participatory principles, and governance principles; good governance; and the principle of regional autonomy. ${ }^{14}$ Therefore, waste management is a form of state responsibility through the government and local governments. Where it takes community participation to carry out its management. Besides, it is strengthened by Article 63 of the UUPPLH which regulates the authority of the government and local governments in environmental protection and management.

Waste is also regulated in Act 18/2008 on Waste Management where it is said that the Law on Waste Management is based on the large population of Indonesia with a high growth rate increases the volume of waste. Also, the consumption pattern of the community has contributed to an increasingly diverse type of waste, among others, packaging waste that is dangerous and/or difficult to decompose by natural processes is increasingly diverse. The substance of this law is directly related to waste management. Article 19 regulates the management of household waste and household-like waste, the article states that the management of household waste and household-like waste consists of reducing waste and handling waste. In terms of reducing waste, it is further stated in Article 20 as follows: Reduction of waste referred to in the following activities: (1) reduction of waste; (2)

${ }^{14}$ N. Listiyani \& M. Yasir Said, (2018), "Political Law on the Environment: The Authority of the Government and Local Government to File Litigation in Law Number 32 Year 2009 on Environmental Protection and Management", Resources, Vol. 7, Issue.4, P.77 
recycling; and/or (3) reuse. Article 20 paragraph (2) regulates that the government and regional governments are obliged to carry out the following activities: (1) to set a gradual waste reduction target within a certain time; (2) facilitate the application of eco-technology; (3) facilitate the application of eco-product labels; (4) facilitating re-use and recycling activities; (5) facilitate the marketing of recycled products. Article 20 paragraph (3) regulates business actors in carrying out activities, namely using production materials that generate as little waste as possible, can be reused, can be recycled, and/or can be easily broken down by natural processes. Article 20 paragraph (4) regulates the community in carrying out waste reduction activities, namely using materials that can be reused, recycled, and/or easily broken down by natural processes.

Waste handling is regulated in Article 22 of Act 18/2008, which includes:

a. Sorting the waste in the form of grouping and separating the waste according to the type, amount, and/or nature of the waste;

b. Collection in the form of collecting and transferring the waste from the waste source to a temporary shelter or integrated waste processing facility;

c. Transportation in the form of carrying waste from the source and/or from a temporary garbage collection site or from an integrated waste processing facility to the final processing site;

d. processing in the form of changing the characteristics, composition, and amount of waste; and/or

e. final waste processing in the form of returning waste and/or residue from previous processing to environmental media safely.

Act 18/2008 on Waste Management should be able to handle problems regarding waste in Indonesia. This law adopted the 3R concept: Reduction - Reuse - Recycling. Likewise with the waste management paradigm, if all this time using the conventional concept, namely waste is considered waste so that it is disposed of which requires disposal costs and ultimately becomes a health threat to the community. So now a new paradigm is being used which views waste as a resource that should be reprocessed to generate income that leads to new job opportunities and opportunities to earn new income.

In the practice of the Banjarmasin City Environmental Service and TPA Basirih in dealing with the problem of plastic waste use JAKSTRADA (Regional Policies and Strategies) and JAKSTRANAS (National Policies and Strategies) as contained in Presidential Regulation 97/2017), Banjarmasin Mayor Regulation 18/2016, Regional Regulation of Banjarmasin City 21/2011. However, both the Banjarmasin City Environmental Service and Basirih TPA do not refer to / use the South Kalimantan Regional Regulation 8/2018. So the Banjarmasin City Environmental Service and TPAs in Banjarmasin should have synergized 
policies with the Provincial Government through the Regional TPA as mandated by the Regional Regulation of the Province of South Kalimantan 8/2019 on the Implementation of Waste Management. However, JAKSTRANAS and JAKSTRADA are policies and strategies mandated by Act 18/2008. Then again referring to rechtsbeginsel and rechtsnorm from Act $18 / 2008$, the legal concept of waste management must be implemented synergistically, integratively, and based on environmental ethics so that the negative policies of the Banjarmasin City Environmental Service and TPA Basirih do not refer to the South Kalimantan Regional Regulation 8/2018 is a mistake, considering that law is a system, each component must be synergistic to produce good law enforcement.

\section{Ius Constitutum and Ius Constituendum as Political Processes of Environmental Law in Indonesia}

Some jurist argues that environmental issues are a policy issue, therefore environmental issues are included as political issues. R.K. Dwi Susilo stated that talking about politics also means talking about power and authority. Then, discussing both of them will be closely related to what is known as a policy. ${ }^{15}$ Therefore, the issue of policy in the environmental sector is an environmental policy. Environmental damage in Indonesia is caused more by mistakes in state policies than by the hands of ordinary people according to Chalid Muhammad. ${ }^{16}$ The politics of environmental law are the direction of legal policies established by the state or government to achieve the goals and objectives of environmental protection and management. However, in reality, environmental law seems unable to carry out its function properly with the emergence of various environmental problems, one of the causes of environmental problems according to Muhammad Akib, has not been understood, implemented, and enforced the principles and norms of environmental law comprehensively following the political law. ${ }^{17}$ According to Utrecht, politics of law investigates what changes must be made in the current law to conform to social realities. Political law makes an Ius constituendum (the future ideal law) and tries to make the Ius constituendum one day act as an Ius constitutum (the applicable law). ${ }^{18}$

\footnotetext{
${ }^{15}$ RK Dwi Susilo, (2009), Sosiologi Lingkungan, Jakarta: RajaGrafindo Persada, P. 132.

${ }^{16}$ Chalid Muhammad, "Pulihkan Indonesia!", Harian Kompas, Monday, 6 June 2011

17 Muhammad Akib, (2013), Politik Hukum Lingkungan: Dinamika dan Refleksinya dalam Produk Hukum Otonomi Daerah, Jakarta: RajaGrafindo Persada, P. ix.

${ }^{18}$ Abdul Latif dan Hasbih Ali, (2011), Politik Hukum, Jakarta: PT. Sinar Grafika, PP. 22-23.
} 
Satjipto Rahardjo argued that legal politics is an activity of choosing and the means to be used to achieve certain social and legal goals in society. Substantially, legal politics is directed at the law which should apply (Ius constituendum). Meanwhile, the definition of legal politics according to Muchtar Kusumatmadja is legal and statutory policies in the framework of legal reform. The process of forming a law must be able to accommodate all matters relevant to the field or problem to be regulated in that law if the law is an effective legal arrangement. ${ }^{19}$ According to Padmo Wahjono, legal politics is a policy of state administrators which is fundamental in determining the direction, form, and content of the law to be formed and about what is used as the criterion for punishing something, in other words, legal politics is related to the applicable law in the future (Ius constituendum). ${ }^{20}$ Teuku Mohammad Radie put forward legal politics as a statement of the will of the state rulers regarding the laws that apply in their areas and regarding the direction of development of the laws that are being built. The legal statement that applies in its territory contains the meaning of the law in effect at this time (Ius constitutum), and regarding the direction of development of the law being developed, contains the meaning of the law that will apply in the future (Ius constituendum). ${ }^{21}$

The direction of the political policy of national environmental law in the field of waste management is based on the desire to reform the system and politics of environmental law, which according to researchers, must be based on 5 (five) basic principles that must be upheld in environmental law, namely: (1) the rule of law; (2) Equality before the Law; (3) Environmental Ethics; (4) Harmony; and (5) Law Enforcement by Law. These five basic principles are an absolute requirement in realizing the aspirations of a prosperous and environmentally friendly Indonesia. If the law is enforced and order is realized, it is hoped that certainty, a sense of security, peace, or a harmonious life will be realized. For this reason, national legal politics must always be directed at efforts to overcome various problems in the development of society. To support the reform of the legal system and politics, a political goal of national law has been established, namely the creation of a national legal system that is just, consistent, and non-discriminatory. As well as ensuring the consistency of all laws and regulations at the central and regional levels, as well as not contradicting higher regulations and laws.

\footnotetext{
${ }^{19}$ Ibid P. 24

20 Imam Syaukani dan A. Ahsin Thoari, (2010), Dasar-Dasar Politik Hukum, Jakarta: PT. Raja Grafindo Persada, PP. 26-27

${ }^{21}$ Ibid.
} 


\section{The Welfare State Theory and John Rawls's Theory of Justice as Ground Theory for Forming the Future Policy of Plastic Waste Management}

In the preamble of the 1945 Constitution, especially concerning the issue of the objective of the Indonesian state is "to advance the general welfare and the intellectual life of the nation based on the principle of social justice for all people of Indonesia". The objectives contained in the preamble were then contained in the body of the 1945 Constitution outlined in various provisions concerning the welfare of the people. Article 1 paragraph (3) of the 1945 Constitution, it also states that: "Indonesia based on the rule of law". Initially, the term rule of law was included in the Explanation of the 1945 Constitution, which was enclosed in parentheses for the Dutch word "rechtsstaat". At first glance, this indicates that the nation's founders at that time adopted the rule of law ideology which was commonly adopted by Continental European countries such as the Netherlands, Germany, France, and so on. However, the statement that Indonesia is a constitutional state is not solely based on normative facts as emphasized in Article 1 paragraph (3) of the 1945 Constitution of the Republic of Indonesia.

Various provisions on economic issues and people's welfare are contained in articles 27 paragraph (2), 31, 32, 33, and 34. Article 27 paragraph (2) stipulates that every citizen has the right to work and a living that is decent for humanity, article 31 stipulates that every citizen has the right to receive instruction. Meanwhile, article 32 stipulates the government's duty to promote national culture, and article 34 stipulates that the poor and neglected children are cared for by the state. Meanwhile, Article 33 regulates economic matters, which adopts a family system, and determines that the production branches which are important for the people and the land and water, and the natural resources above it are controlled by the state.

After the amendment to the 1945 Constitution, especially the second amendment, the articles regarding the economy and people's welfare were added, namely by article $28 \mathrm{H}$ which reads:

(1) Every person has the right to live in physical and mental prosperity, to live, and to have a good and healthy environment, and the right to get health services.

(2) Every person has the right to get special facilities and treatment to get the same opportunities and benefits to achieve equality and justice.

(3) Every person has the right to social security which enables his complete selfdevelopment as a dignified human being.

(4) Every person has the right to own private property and these rights cannot be taken over arbitrarily by anyone. 
A welfare state is a state that guarantees the implementation of people's welfare. In realizing the people's welfare should be based on the five pillars of the state, namely: Democracy, Rule of Law, Human Rights, Social Justice, and Anti-Discrimination. One of the originators of the welfare state theory, R. Kranenburg, stated that the state must actively strive for welfare, and act fairly that can be felt by all people equally and equally, not only for the welfare of certain groups but all levels of society. Article $28 \mathrm{H}$ paragraph (1) contains the content that everyone has the right to a good and healthy environment, as an inseparable human right. So in the formulation of a norm ius constituendum for good waste management as a form of eco-development, the concept of a Welfare State also includes welfare in obtaining a good living environment to ensure the protection of human rights and justice for the Indonesian people.

Furthermore, referring to Justice, we take Justice as conceptualized by John Rawls who is a philosopher in the field of moral philosophy and political philosophy. Rawls puts forward two principles regarding justice, namely ${ }^{22}$ :

1. Everyone should have the same rights over the broadest comprehensive system of basic liberties/basic rights.

2. Social and economic differences should be arranged in such a way as to

a. provide the greatest benefit to those in the most disadvantaged position.

b. Relating to positions and positions open to all based on proper equality of opportunity.

The theory of justice put forward by John Rawls is heavily influenced by the Theory of Choice $^{23}$ which is seen as prioritizing the principle of rights over the principle of benefit. Rawls proposes a contract-based theory of justice, as well as offers a concrete method for making the most fundamental decisions regarding distributive justice, namely "justice as fairness". 24

John Rawls in his book "A Theory of Justice" emphasizes that the theory of justice is a method for studying and producing justice. There are thought procedures to produce justice. In this case, Rawls argues that different principles will only work if the first principle works

\footnotetext{
${ }^{22}$ The Liang Gie, (1979), Teori-Teori Keadilan, Yogyakarta: Super, P. 36

${ }^{23}$ Lily Rasyidi, (1988), Filsafat Hukum, apakah hukum itu, Remaja Karya, P. 83.

${ }^{24}$ Karen Leback, (2012), Teori-Teori Keadilan Six Theories of Justice, Bandung: Nusa Media, PP. 49-
} 50. 
or in other words, the difference principle will work if basic rights none of revoked (Human Rights are Fulfilled). ${ }^{25}$ Rawls' principle emphasizes that there must be a fulfillment of something more basic so that something else can be fulfilled. ${ }^{26}$ So in other words, economic improvement and community welfare will only be achieved if human rights have been fulfilled, in this case including the protection of human rights to obtain a healthy environment.

\section{Deep Environmental Ethics As Fundamental Virtue in Future Policy}

In essence, the environmental problem is a moral issue, the solution of environmental problems can not be approached technically only partially. Environmental issues must be approached more comprehensively-holistically, including morally. ${ }^{27}$ The environment, according to Sonny Keraf, is not purely technical. Likewise, the global ecological crisis that we have today is a moral issue, namely a global moral crisis. Therefore, ethics and morality are needed to overcome it. ${ }^{28}$ Ethical values according to Emil Salim are first influenced by the deepening of one's religion. In the development of human life, other factors influence human moral values, namely the conditions of the social environment and the natural environment in which humans thrive. ${ }^{29}$ Emil Salim further stated that the aspects that affect human relations with the environment are determined by environmental ethics. Arne Naess said that the current environmental crisis can only be resolved by changing the way humans perceive and behave towards nature fundamentally and radically. It takes a new lifestyle or lifestyle that concerns not only individuals but also the culture of society as a whole. This means that environmental ethics is needed that guides humans to interact in a new way in the universe. Ethics is a moral philosophy, or science that critically discusses and studies the issue of moral right and wrong, about how to act in concrete situations. The wrong mindset and human action patterns in responding to nature and managing the various energies and materials contained in it have brought about the greatest human tragedy in the form of a sustainable environmental crisis. Since the industrial revolution with massive technological factories and equipment that is rapidly developing, the exploitation and destruction of natural entities such as species, individuals, and ecosystems have occurred. This makes people stunned and raises awareness of green movements, and also understands environmental ethics from the point of

\footnotetext{
${ }^{25}$ John Rawls, (2009), “A Theory of Justice”, Revised Edition, USA: Harvard University Press, PP. 4-5.

${ }^{26}$ M. Yasir Said \& Yati Nurhayati, (2021), "A Review on Rawls Theory of Justice", International Journal of Law, Environment, and Natural Resource (INJURLENS), Vol. 1, No.1 March 2021, PP. 1-20

${ }^{27}$ Sonny Keraf, (2010), Etika Lingkungan Hidup, Jakarta: Kompas, P. 2

${ }^{28}$ Ibid., P.1

${ }^{29}$ Emil Salim, (2000), Kembali Ke Jalan Lurus: Esai-esai 1966-1999, Jakarta: Alfabet, P.190.
} 
view of environmental philosophy. Environmental philosophy is a new philosophy proposed by Henryk Skolimowski by considering the relationship between one individual and another and also with their environment, as a comparison with the contemporary philosophy of modernism. ${ }^{30}$ The perspective and behavior of humans in interacting, both with nature and with other humans in the entire ecosystem, actually exists in traditional communities or indigenous peoples with their traditional knowledge which is also known as local wisdom. ${ }^{31}$ Traditional communities or indigenous peoples with their traditional knowledge are better able to preserve the environment than modern life. Traditional communities have broad and deep knowledge in the protection and management of their respective natural or natural environments, which are used to best manage their resources. However, over time, various laws and regulations generally do not accommodate the interests of these indigenous peoples. $^{32}$

Environmental ethics according to Sonny Keraf is understood as a scientific discipline that talks about moral norms and rules that govern human behavior in dealing with nature as well as moral values and principles that animate human behavior in dealing with nature. ${ }^{33}$ Environmental ethics according to Keraf is a critical reflection on norms and values or moral principles that are commonly known so far concerning the environment and a critical reflection on the way humans perceive humans, nature, and the relationship between humans and nature as well as behavior that comes from that point of view. this. From this critical reflection, new perspectives and behaviors that are considered more appropriate, especially in the framework of saving the environmental crisis, are presented. ${ }^{34}$

So holding on to a shift because of nature, researchers argue that the view of Ecocentrism (Deep Environmental Ethics) is the answer to environmental problems including plastic waste management in Indonesia. Ecocentrism is a development of biocentrism's environmental ethical theory. Ecocentrism focuses ethics on all ecological communities, both living and nonliving. Ecologically, they are related to each other. Therefore, moral obligations

30 Jared Diamond, (2011), Collapse: How Societies Choose to Fail or Succeed, New Hampshire: Marion Boyars Inc. sebagaimana dikutip oleh Marison Guciano, "Bangsa Tanpa Visi Ekologi”, Kompas, Jumat, 3 Februari 2012.

${ }^{31}$ M. Yasir Said \& Yati Nurhayati, (2020), "Paradigma Filsafat Etika Lingkungan Dalam Menentukan Arah Politik Hukum Lingkungan", Al-Adl: Jurnal Hukum, Vol.12, No.1, PP.39-60

32 Eko Nurmadiansyah, (2014), "Eco-Philosophy dan Implikasinya Dalam Politik Hukum Lingkungan Di Indonesia” Jurnal Melintas, Vol.30, No.1, 2014, PP.70-104.

${ }^{33}$ Sonny Keraf, op. cit., P. 40.

${ }^{34}$ Ibid., P.21 
and responsibilities are not limited to living things. The same moral obligations and responsibilities apply to all ecological realities. The Biosentrisme environment itself is a lifecentered theory of environment. The essence of biocentrism theory is that humans have a moral obligation to nature. This obligation does not originate from human obligations towards others, as understood by anthropocentrism. This obligation originates and is based on the consideration that life is something of value, whether human life or the life of other species. Environmental ethics is not a branch of human ethics according to this theory. Environmental ethics broadens human ethics to apply to all living things. Biocentrism itself is a form of thought that opposes the theory of Anthropocentrism as a theory of environmental ethics that views humans as the center of the universal system. Humans and their interests are considered to be the most decisive in the ecosystem order and in the policies that are taken with nature, either directly or indirectly. The highest value is humans and their interests, only humans have value and get attention, everything else in this universe will only get value and attention as long as it supports and is for the benefit of humans. Therefore, nature is seen only as an object, tool, and means for the fulfillment of human needs and interests. Nature is only a tool for the attainment of human goals. Nature has no value in itself. ${ }^{35}$

Ecocentrism and Biocentrism break the Anthropocentrism perspective which limits the application of ethics only to the human community. Both broaden ethical applicability to encompass a wider community. In biocentrism, ethics is extended to include the biotic community. Meanwhile, in eco-centrism, ethics is extended to cover the whole ecological community. $^{36}$

This ecocentric ethic is rooted in a holistic, not mechanistic, way of thinking about all reality. This way of thinking holistic has 5 (five) assumptions, according to Agus Rachmat, as follows ${ }^{37}$ :

1. Everything that exists is related to one another to form one whole. The whole (totality) affects every part of it; and conversely, changes that occur in one part will also change the other part and the whole as well. So, for example, in an ecosystem there are so many changes in its parts, that in the end, the whole ecosystem will collapse;

2. The whole is greater than the sum of its constituent parts. The principle governing an ecosystem is not the principle of identity which states that the whole is identical with the total number of its parts, but the principle of synergy: combining several forces

\footnotetext{
${ }^{35}$ Ibid., P.47.

${ }^{36}$ Ibid., P. 92

37 Agus Rachmat, "Etika Lingkungan Hidup dan Pertentangan Politik", in Bambang Sugiharto dan Agus Rachmat, (2000), Wajah Baru Etika dan Agama, Yogyakarta: Kanisius, PP. 75-76.
} 
into one unit will produce greater power and impact than if each force were to work alone;

3. The meaning depends on the context. Unlike the mechanism which emphasizes that each thing is independent and can be understood in isolation, this holism emphasizes that everything or event derives its meaning because of its relationship to other things and thanks to its role in the whole;

4. The process takes precedence over its parts. A certain whole, for example, a social or biological system, is always open and dynamic, meaning that there is always exchange and circulation of matter and energy between a system and its environment. The parts that make up a whole are not permanent but are constantly changing and changing thanks to the process of exchanging and cyclic energy. As a result, new things and whole arrangements can always arise. This process of change and creativity are essential features of reality;

5. Humans and the non-human natural environment form one unit. In holism, there is no dualistic conflict between nature/culture. Humans and nature are seen as two parts of the same system of cosmic organisms. In other words, holism pays more attention to continuity, and not conflict, between humans and nature and seeks to study the reciprocal influence between humans/society and their natural environment.

One version of the theory of eco-centrism is the theory of environmental ethics which is currently popularly known as deep ecology. As a term, deep ecology was first introduced by Arne Naess, a Norwegian philosopher, in 1973. Naess became known as one of the main figures of the movement of deep ecology until now. In his article entitled "The Shallow and the Deep, Long-range Ecological Movement: A Summary", Naess distinguishes between shallow ecological movement and deep. ecological movement. The concept of Deep ecology demands a new ethic that is not centered on humans, but which centers on living things entirely by trying to solve environmental problems. This new ethic has not completely changed the relationship between humans and humans. That, humans and their interests are no longer the centers of the moral world. Indeep ecology fact focuses on all species, including non-human species. In short, to the entire biosphere. Likewise, deep ecology is not only concerned with short-term, but long-term interests. Thus, the moral principles developed by deep ecology concern the interests of the entire ecological community. ${ }^{38}$

Meanwhile, Suwito formulated the concept of deep ecology as an effort to combine aspects of religious spirituality with the environment (eco-spirituality), humans are part of nature and nature is sacred and sacred. ${ }^{39}$ Suwito argues that deep ecology with a variety of

${ }^{38}$ Sonny Keraf, Op. Cit., P. 50.

39 Suwito NS, (2011), Eko-Sufisme: Konsep, Strategi, dan Dampak, Purwokerto: STAIN Press \& Yogyakarta: Buku Litera, P.viii 
findings is closer to eco-Sufism. ${ }^{40}$ According to Suwito, eco-Sufism can mean ecology-based Sufism, which means spiritual awareness obtained by interpreting the interactions between systems of existence, especially in the surrounding environment. ${ }^{41}$ Eco-Sufism or green Sufism is a new concept of Sufism that is constructed through the unification of awareness between environmental consciousness and divinity. So that according to the opinion of researchers in formulating the policy of constituency environmental in the field of plastic waste management. In particular, the viewpoint must be established that the policy direction of the ius constituendum is not only aimed at providing protection of the right to the environment for humans but also changing the paradigm and environmental views towards Ecocentrism and Deep Ecology rather than the views of Anthropocentrism and Shallow Ecology.

\section{CONCLUSION}

The Banjarmasin City Environmental Service and TPA Basirih in dealing with the problem of plastic waste used JAKSTRADA and JAKSTRANAS as the ground for enforcement as contained in Presidential Regulation 97/2017, Banjarmasin Mayor Regulation 18/2016, Regional Regulation of Banjarmasin City 21/2011. However, both the Banjarmasin City Environmental Service and Basirih TPA do not refer to / use the South Kalimantan Regional Regulation 8/2018.

As for formulating future policy of plastic waste management. First of all, the viewpoint must be established that the policy direction of the ius constituendum is not only aimed at providing protection of the right to the environment for humans but also changing the environmental paradigm and outlook towards Ecocentrism and Deep Ecology rather than the views of Anthropocentrism and Shallow Ecology.

\section{Book}

\section{REFERENCE}

Abdul Latif dan Hasbih Ali, (2011), Politik Hukum, Jakarta: PT. Sinar Grafika, PP. 22-23

Bambang Sugiharto dan Agus Rachmat, (2000), Wajah Baru Etika dan Agama, Yogyakarta: Kanisius, PP. 75-76.

Emil Salim, (2000), Kembali Ke Jalan Lurus: Esai-esai 1966-1999, Jakarta: Alfabet, P.190.

40 Orientation to personal safety can be directed more positively and has a good impact on the environment, if the self / ego tries to harmonize itself with the divine, others, and the universe. Ibid.

${ }^{41}$ Ibid., P. 47. 
Imam Syaukani dan A. Ahsin Thoari, (2010), Dasar-Dasar Politik Hukum, Jakarta: PT. Raja Grafindo Persada, PP. 26-27.

John Rawls, (2009), "A Theory of Justice", Revised Edition, USA: Harvard University Press, PP. 4-5.

Jared Diamond, (2011), Collapse: How Societies Choose to Fail or Succeed, New Hampshire: Marion Boyars Inc.

Karen Leback, (2012), Teori-Teori Keadilan Six Theories of Justice, Bandung: Nusa Media, PP. 49-50.

Lily Rasyidi, (1988), Filsafat Hukum, apakah hukum itu, Remaja Karya, P. 83

Muhammad Akib, (2013), Politik Hukum Lingkungan: Dinamika dan Refleksinya dalam Produk Hukum Otonomi Daerah, Jakarta: RajaGrafindo Persada, P. ix.

M. Yasir Said \& Ifrani, (2019), Hukum Pidana Kehutanan Indonesia: Pergeseran Delik Pidana Kehutanan Menjadi Premium Remedium, Bandung: Nusa Media, P. 100

R.K. Dwi Susilo, (2009), Sosiologi Lingkungan, Jakarta: RajaGrafindo Persada, P. 132.

Soetandjo Wignjosoebtoto, (2002), Hukum-Paradigma, Metode dan Dinamika Masalahnya, Jakarta: ELSAM dan HUMA, P. 69.

Suwito NS, (2011), Eko-Sufisme: Konsep, Strategi, dan Dampak, Purwokerto: STAIN Press \& Yogyakarta: Buku Litera, P.viii.

The Liang Gie, (1979), Teori-Teori Keadilan, Yogyakarta: Super, P. 36

\section{Journal}

Aneta K. Urbanek et.al., (2017), "Isolation and Characterization of Arctic Microorganisms Decomposing Bioplastics", AMB Express, Vol.7, No.1, PP. 1-10, https://doi.org/10.1186/s13568-017-0448-4

Balint Horvath, Edmund Mallinguh, Csaba Fogarassy, (2018), "Designing Business Solutions for Plastic Waste Management to Enhance Circular Transitions in Kenya", Sustainability, Vol.10, No.5, P.1664, https://doi.org/10.3390/su10051664.

Chalid Muhammad, “Pulihkan Indonesia!”, Harian Kompas, Monday, 6 June 2011

Eko Nurmadiansyah, (2014), "Eco-Philosophy dan Implikasinya Dalam Politik Hukum Lingkungan Di Indonesia” Jurnal Melintas, Vol.30, No.1, 2014, PP.70-104.

M. Yasir Said \& Yati Nurhayati, (2020), "Paradigma Filsafat Etika Lingkungan Dalam Menentukan Arah Politik Hukum Lingkungan", Al-Adl: Jurnal Hukum, Vol.12, No.1, PP.39-60. 
M. Yasir Said \& Yati Nurhayati, (2021), "A Review on Rawls Theory of Justice", International Journal of Law, Environment, and Natural Resource (INJURLENS), Vol. 1, No.1 March 2021, PP. 1-20.

Mele Caterina, (2019), "Human Settlements And Sustainability: A Crucial And Open Issue", E3S Web of Conferences, Volume 119, P.12, https://doi.org/10.1051/e3sconf/201911900012.

Mangal Gogte, (2009), “Are Plastic Grocery Bags Sacking The Environment?”, International Journal For Quality Research, Vol. 3, No.4, PP. 363-375.

Mulyanto, (2013), "Sistem Pengelolaan Sampah Terpadu (Sipengestu) Kelurahan Serengan dalam Kajian Sosiologi Hukum”, Jurnal Parental, Vol. 1, No. 2 October 2013, P. 6

Nora-Charlotte Pauli, Jana S. Petermann, Christian Lott, Miriam Weber, (2017), "Macrofouling Communities and the Degradation of Plastic Bags in the Sea: An in Situ Experiment", Royal Society Open Science, Vol. 4, No. 10, P. 1, https://doi.org/10.1098/rsos.170549

N. Listiyani \& M. Yasir Said, (2018), "Political Law on the Environment: The Authority of the Government and Local Government to File Litigation in Law Number 32 Year 2009 on Environmental Protection and Management", Resources, Vol. 7, Issue.4, P.77

Nurhenu Karuniastuti, (2013), "Bahaya Plastik Terhadap Kesehatan dan Lingkungan”, Jurnal Forum Teknologi, Vol. 03 No.1, PP. 6-7.

Yati Nurhayati, Ifrani, M.Yasir Said, (2021), "Metodologi Normatif dan Empiris Dalam Ilmu Hukum”, Jurnal Penegakan Hukum Indonesia, Vol. 2, No.1, Januari 2021, PP.120.

Yati Nurhayati, Ifrani, Abdul Halim Barkatullah, M Yasir Said, (2019), "The Issue of Copyright Infringement in 4.0 Industrial Revolution: Indonesian Case", Jurnal Media Hukum, Vol.26, No.2 December 2019, PP.122-130.

Sonny Keraf, (2010), Etika Lingkungan Hidup, Jakarta: Kompas, P. 2.

Marison Guciano, "Bangsa Tanpa Visi Ekologi”, Kompas, Jumat, 3 Februari 2012.-startupfintech-di-indonesia. 